\title{
Iteratiivse või duratiivse tegevuse väljendamisest vene ja eesti keeles
}

\author{
SIRJE KUPP-SAZONOV \\ Tartu Ülikool
}

Ülevaade. Uurimus keskendub iteratiivse või duratiivse tegevuse väljendusvõimaluste analüüsimisele vene ja eesti keeles. Kõrvutades erinevaid vene ilukirjandustekste nende eestikeelsete tõlgetega, võib täheldada, et eesti keel vajab iteratiivse või duratiivse tegevuse väljendamiseks reeglina rohkem erinevaid keelelisi vahendeid kui vene keel. Viimases piisab sageli vaid verbi kasutamisest imperfektiivses aspektis (vn несовершенный вид) ning erinevad määrsõnad jms vaid toetavad iteratiivse või duratiivse tegevuse väljendamist, samas, kui eestikeelses lauses võivad need leksikaalsed vahendid eespool mainitud tähendused täiesti enda kanda võtta. Mõnikord võib kahe keele vaheliste erinevuste arvestamata jätmine viia öeldu mitmeti mõistmiseni.

Võtmesõnad: kontrastiivne keeleuurimine, iteratiivsus, duratiivsus, vene keel, eesti keel

\section{Sissejuhatuseks}

Artiklis vaadeldakse iteratiivse või duratiivse tegevuse väljendamist vene ja eesti keeles. Sellised kontrastiivsed uurimused pakuvad materjali, mida edaspidi saab kasutada nt keeleõppes, samuti tõlkealastes teoreetilistes ja praktilistes käsitlustes. Analüüsi eesmärk on selgitada välja, milliseid keelelisi (eelkõige grammatilisi) vahendeid on vaja vene ja eesti keeles rakendada iteratiivse või duratiivse tegevuse väljendamiseks. Artiklis otsitakse vastust kahele uurimusküsimusele: 
1) Kuidas täpsemalt eesti keeles kompenseeritakse asjaolu, et vene keeles on iteratiivse või duratiivse tegevuse väljendamine peamiselt verbiaspekti ülesanne ning teistel keelelistel vahenditel on vaid toetav funktsioon?

2) Millised vaadeldavate tähenduste väljendusvõimalused kõrvutatavates keeltes kattuvad ning millised esinevad vaid ühes või teises keeles?

"Eesti keele grammatikas" on öeldud, et "sündmuse enda täpsem toimumisviis aja seisukohalt, st see, kas tegemist on ühekordse või korduva tegevusega või hoopis pideva ja katkematu protsessiga, kas ja kui palju sündmus kestab enne või pärast vaatlushetke jms, selgub lauses verbi tegevuslaadi, aspekti, ajamääruse jms toimel” (EKG I 1995: 76).

Selles artiklis käsitletakse duratiivsust ja iteratiivsust hierarhilises mõttes võrdväärsetena, kuid on keeleteadlasi, kelle meelest pole see nii. Näiteks Helena Sulkala, viidates Eeva Kangasmaa-Minnile (1985: 433), väidab, et verbid võib jagada kahte rühma: duratiivsed (väljendavad kestvat protsessi) ja punktuaalsed (väljendavad tegevust, mis on lõpetatud kohe, kui see on alanud). Duratiivsuse alamkategooriad on kontinuatiivsus, iteratiivsus ja frekventatiivsus (Sulkala 1996: 167). Helena Sulkala rõhutab ka, et oluline on omavahel eristada duratiivsust ja progressiivsust, kuna viimane ei pruugi tingimata rõhutada ajalist kestvust (Sulkala 1996: 192).

Kuigi osa iteratiivse või duratiivse tegevuse väljendusvõimalustest kattuvad kõrvutatavates keeltes (nt adverbiaalid), on siiski ka terve hulk vahendeid (nt vene keele verbiaspekt, eesti keele objekti kääne), mis ei ühti. Vaadeldavate keelte erinevused ja sarnasused kõnealuste tähenduste väljendamisel selgitatakse välja kontrastiivse lingvistilise analüüsi abil. Analüüsitav materjal pärineb ilukirjandusest, täpsemalt vaadeldakse venekeelseid originaaltekste ja nende eestikeelseid tõlkeid. Loomulikult saab sellist uurimust läbi viia ka kasutades vene- ja eestikeelseid originaaltekste, kuid praeguses uurimuses eelistatakse kasutada tõlkeid peamiselt ühel kaalutlusel. Nimelt võib eeldada, et kuna tõlkes üritatakse võimalikult täpselt anda edasi algteksti sisu, aga keelte 
grammatikasüsteemid on teadupärast erinevad, siis tulevad lähte- ja sihtkeelse teksti kõrvutamisel keeltevahelised erinevused veelgi selgemalt esile. Selle väite illustreerimiseks sobivad näitelaused (1a) ja (1b). Venekeelse teksti puhul ei teki tänu verbiaspektile mitte mingisugust küsimust tegevuse iseloomu kohta, kirjeldatud olukord leidis minevikus aset rohkem kui üks kord. Samas lubab eestikeelne tõlkelause (1b) oletada, et kõik kirjeldatud tegevused ei ole iteratiivsed.

(1a) Она приходила, и первым долгом надевала фартук, и в узкой передней, где находилась та самая раковина, которой гордился почему-то бедный больной, на деревянном столе зажигала керосинку, и готовила завтрак, и накрывала его в первой комнате на овальном столе. (М. Булгаков)

(1b) Naine tuli, pani kõigepealt põlle ette, sü̈̈tas priimuse puulaual sellessamas kitsas esikus, kus asus kraanikauss, mille üle vaene haige miskipärast nii uhke oli, tegi süüa ja kattis siis ovaalse laua esimeses toas. (Tlk. M. Varik ja J. Ojamaa)

Järgnevalt vaadeldaksegi üksikasjalikumalt mõlema keele võimalusi iteratiivse või duratiivse tegevuse väljendamiseks.

\section{Iteratiivse tegevuse väljendusvõimalused vene ja eesti keeles}

\subsection{Verbiaspekt}

Aspektikategooria abil on võimalik väljendada tegevuse olemust, kas see on terminatiivne / mitteterminatiivne, perfektiivne / imperfektiivne, resultatiivne / irresultatiivne, duratiivne / momentaanne või iteratiivne / mitteiteratiivne (Bondarko 1971: 4). Aspektuaalsus laiemalt on universaalne kategooria, mis väljendub nii vene kui ka eesti keeles ning selle edasiandmiseks eksisteerivad keeltes erinevad võimalused.

Aspektikategooria on käsitlemist leidnud mitmetes tüpoloogilistes (nt Dahl 1985; Comrie 1995 jt) ja kontrastiivsetes (nt Tommola 1986; Sulkala 1996 jt) uurimustes. Aspektikategooria väljendumist vene ja 
eesti keeles on varasemalt põhjalikumalt uuritud järgmiste keeleteadlaste töödes Ants Pihlak (1978; 1982), Pille Eslon ja Ants Pihlak (1993), Irina Külmoja jt (2003), Natalia Vaiss (2004), Sirje Kupp-Sazonov (2012; 2015) jt.

Vene keeles väljendub aspektuaalsus eelkõige verbiaspektis (vn вud), mis on omane ka teistele slaavi keeltele ning mida eesti keeles eraldiseisva kategooriana ei ole. Seetõttu räägitakse russistikas traditsiooniliselt ka aspekti ajavormidest (видовременные формь), mis on igati õigustatud, kuna kindlas kõneviisis on aspektikategooria lahutamatult seotud ajakategooriaga. Nii imperfektiivsel kui ka perfektiivsel verbiaspektil on mitmeid erinevaid tähendusi (vt Bondarko 1971: 22-31), mh väljendatakse ka iteratiivset või duratiivset tegevust. Mõningate vene verbipaaride puhul on võimalik eesti keeles leida eraldi vasted, näiteks imperfektiivne aspekt: говорить 'rääkima' ja perfektiivne aspekt: сказать 'ütlema', aga paljudel juhtudel pole see nii, näiteks: бpamь ja взять 'võtma', открывать ja открыльь 'avama' jne. Kuigi Pihlak on kunagi välja öelnud arvamuse, et ka mõningaid eesti keele ajavorme, eelkõige perfekti ja pluskvamperfekti, võiks tõlgendada aspekti ajavormidena (Pihlak 1978: 28), on mitmed lingvistid leidnud, et eesti keeles väljendub aspektuaalsus siiski eelkõige lauses tervikuna, kuna lisaks verbi grammatilisele vormile ja leksikaalsele tähendusele sõltub aspekt ka kontekstist ja teistest lauseliikmetest (Seilenthal 1988: 53; Metslang 1994: 18; Nemvalts 2000: 125). Helle Metslang on tõdenud, et "imperfektiivsuse / perfektiivsuse opositsiooni väljendamiseks on keeles olemas küll piiratud, kuid siiski väljakujunenud vahendid, nagu sihitise vorm, afiksaaladverbid, latiivsed määrused" (Metslang 1993: 413).

Aspektuaalsuse väljendusvõimalusi eesti keeles on liigitatud mitmeti, näiteks "Eesti ja vene keele kontrastiivgrammatika väikese käsiraamatu” (Külmoja jt 2003: 89-91) autorid leiavad, et vene keele aspekti saab eesti keeles anda edasi kolme tüüpi vahenditega:

1) sõnamoodustusvahendid - näiteks kestva tegevuse tähistamiseks sobivad sufiksid -le-, -skle-, -i-, -tse-: полеживать - lamasklema, грести - rehitsema, летать - lendlema jne. Samas 
vastavad vene keele sufiksile - $н$ y eesti keeles sufiksid -ata-, -ahta-, mis väljendavad mitteiteratiivset, sageli ootamatut tegevust: дрогнуть - võpatama, värahtama;

2) süntaktilised vahendid - partsiaal- ja totaalobjekt. Siinkohal on oluline meeles pidada, et küllaltki sageli võivad objekti nominatiivi, genitiivi ja partitiivi vormid kokku langeda (Metslang 2001: 444), nt lauset Lind ehitas pesa võib tõlgendada nii duratiivse kui ka terminatiivse tegevusena;

3) leksikaalvahendid - verbid, mis tähistavad tegevuse algust, nt запел - hakkas laulma, заплакал - puhkes питта, побежал pistis jooksma. Sellesse gruppi kuuluvad ka erinevad adverbid, väljendid, mis tegevuse toimumise kulgu iseloomustavad.

Vaiss loeb oma magistritöös leksikaalsete väljendusviiside hulka ka verbilekseemi semantilise tähenduse (nt kõnelema/rääkima - ütlema; lugema - läbi lugema; tegema - ära tegema), reduplikatsiooni (nt jookseb ja jookseb; päevad lähevad üha pikemaks ja pikemaks) ning teised kontekstuaalsed võimalused. Samasse rühma liigituvad ka momentaanset ja frekventatiivset tähendust lisavad verbisufiksid -ahta-, -ata-; -le-, -skle-, , $i-$, -tse-. Leksikaalgrammatiliste vahendite hulka kuuluvad tegevuslaadid (nt duratiivsust, habituaalsust, progressiivsust, punktuaalsust jt) ja perfektiivsusadverbid (nt ära, läbi, valmis, lõpuni, maha, minema jt). Grammatilisteks väljendusviisideks võib pidada verbi ajavorme ning substantiivifraasi käändevaheldust (Vaiss 2004: 14).

Mis puudutab konkreetselt verbiaspekti, siis kuigi näiteks Mati Erelt eristab eesti keeles imperfektiivseid, perfektiivseid ja neutraalseid verbe, siis ka tema käsitluses ei ole piiritlusaspekt (näitab, kas situatsioon on piiritletud või mitte) verbi morfoloogiline ega derivatiivne kategooria ning aspektivaheldust võimaldavate verbide puhul väljendatakse aspekti verbiväliste vahenditega (Erelt 2013: 71-73).

Erinevate keelte aspektoloogiaalastes uurimustes on kesksel kohal Zeno Vendleri verbide leksikaal-semantiline klassifikatsioon, mille kohaselt jagunevad verbid nelja klassi: seisundid (ingl states), tegevused (activities), saavutused (achievements) ja sooritused (accomplishments) 
(Vendler 1967: 107-108). Verbi kuulumine konkreetsesse rühma määrab ära, kas selle verbiga on võimalik väljendada iteratiivset, duratiivset, momentaanset vms tegevust või seisundit, näiteks saavutused leiavad aset ühes hetkes, samal ajal, kui seisundid kestavad teatud ajaperioodi (Samas 103). Lähtudes vene keele aspektist liigitas Juri Maslov (1948) verbid kolme gruppi: 1. imperfektiivse aspekti verbid, mis ei kuulu aspektipaari; 2. perfektiivse aspekti verbid, mis ei kuulu aspektipaari; 3 . verbid, mis moodustavad aspektipaari. Maslov väitis, et verbi kuulumine ühte klassi tuleneb selle leksikaalsest semantikast (Maslovi ja Vendleri klassifikatsioonide üksikasjaliku kõrvutamise ning sarnasuste ja erinevuste kohta vt Padutševa 2009.)

Lisaks verbiaspektile on ka vene keeles mõningaid teisi aspektuaalsuse väljendusviise, kuigi neid loetakse üldiselt perifeerseteks. Perifeersete aspektuaalsuse väljendusviiside hulka kuuluvad näiteks tegevuslaadid (vene keele kohta vt nt Zaliznjak \& Šmeljov 2000: 104-127; Maslov 2004: 383-387, aga ka Potebnja 1941; Bondarko \& Bulanin 1967; Petruhhina 2009 jt; eesti keele tegevuslaadide kohta vt nt EKG II 1993: 22, aga ka Tamm 2004; Argus 2007 jt), adverbiaalid, reduplikatsioon. Eri autorid ei ole jõudnud kokkuleppele selles, kas aspekti ja tegevuslaadi peaks üldse rangelt eristama või mitte (Norvik \& Piiroja 2013: 65).

Tulles nüüd verbiaspekti abil iteratiivse tegevuse väljendamise juurde, peab märkima, et vene keeles kasutatakse selleks reeglina imperfektiivse aspekti verbe, kuid on ka mõningad erandid (vt näitelauseid (5a), (5b) ja (7a), (7b), (8a), (8b)). Esmalt aga tuleks käsitleda reeglipäraseid juhtumeid, ehk siis neid, kus iteratiivset tegevust antakse edasi just imperfektiivse aspekti verbivormidega. Iteratiivne tegevus võib esineda nii minevikus (2a) ja (2b), olevikus (3a) ja (3b) kui ka tulevikus (4a) ja (4b).

(2а) В четырнадцать лет он спекулировал куревом на территории порта. Покупал у иностранных моряков сигары для ночного ресторана братьев Уриных. Затем перешёл на чулки и косметику. Если требовалось, провожал иностранцев в публичный дом на Косой улице. Параллельно боксировал в атлетическом клубе “Икар". (С. Довлатов) 
(2b) Neljateistaastaselt hangeldas ta sadamas suitsudega. Ostis välismaa meremeestelt sigareid ja müüs vendade Urinite öörestoranile. Seejärel läks ta üle sukkadele ja kosmeetikale. Vajadusel juhatas ta välismaalasi Kossaja tänava lõbumajja. Samal ajal käis ta spordiklubis "Ikarus" poksimas. (Tlk. V. Matsov)

(3а) Я работаю на фабрике, хожу иногда на танцплощадку, встречаюсь с девушками, сами понимаете, не без этого. (А. Рыбаков)

(3b) Mina töötan vabrikus, käin mõnikord tantsuplatsil, kohtun näitsikutega, eks te ise tea, kus siis selleta. (Tlk. L. ja P. Mõtsküla)

(4a) - Давай я буду приходить к тебе на работу, когда ты дежуришь в ночную смену, - предлагал Юрий. (А. Маринина)

(4b) “Teeme nii, et ma hakkan käima su töö juures, kui sa oled valves öises vahetuses," tegi Juri ettepaneku. (Tlk. P. Haaslava)

Ilmselgelt on ka kõikides eestikeelsetes lausetes tegevuste iteratiivsus edasi antud ning selleks on tõlkijad kasutanud erinevaid vahendeid. Näitelauses (2b) on habituaalset ja iteratiivset tegevust väljendatud tarindiga käima + supiini inessiiv (poksimas). Lauses (3b) on peamiseks iteratiivsuse tähenduse kandjaks adverb mõnikord. Tulevikulist olukorda (4b) väljendav analüütiline konstruktsioon hakkama +ma-infinitiiv sobib eriti hästi korduva ja aktiivsema tegevuse edasiandmiseks (Metslang 1997a: 230).

Järgnevalt vaadeldakse kahte võimalust, mil vene keeles ka perfektiivne aspekt võib tähistada iteratiivset tegevust. Esimesel juhul võib rääkida nn näitlikkuse semantikast (наглядно-примерное значение), mis väljendub selles, et ühte iteratiivset tegevust esitletakse kui teiste samasuguste tegevuste näidist (5a). Eesti keeles sobib vasteks perfektivorm (5b).

(5а) Дверь я распахнул, не касаясь ее - толкнул через сумрак. Не знаю, зачем. Со мной редко такое бывает, иногда - если очень много выпью, иногда - если сильно разозлюсь. (С. Лукьяненко)

(5b) Lõin ukse lahti seda puutumata - tõukasin läbi videviku. Ei tea, miks. Minuga juhtub harva nii, ainult mõnikord, kui ma olen väga palju joonud või väga tige. (Tlk. T. Rõigas) 
Teiseks võivad perfektiivse aspekti verbid tähistada iteratiivset situatsiooni nn summaarse tähenduse (vn суммарное значение) puhul, millega väljendatakse seda, et üks terminatiivne tegevus toimub teatud kindla arvu kordi. Olga Rassudova rõhutab, et kõnealuse tähenduse väljendamiseks peab olema täidetud rida tingimusi, mh peab lauses olema kindlasti sõna $p a 3$ (kord), tänu millele on tegevuse korduvus piiritletud (näitelauses (7a) puudub formaalselt sõna pa3, kuid lekseem трижdbl tähendab kolm korda). Summaarset tähendust väljendavad sagedamini verbid prefiksitega nepe- ja npo- ning sufiksiga - $н$ - (Rassudova 1982: 38-39). Oluline on siinkohal pidada silmas, et sellist kasutust võimaldavad vaid need verbid, mis väljendavad tegevust, mille puhul taastub nö algne seisund, seetõttu ei saa vene keeles näiteks öelda:

(6a) ${ }^{*} \mathrm{OH}$ три раза уехал за границу.

(6b) Ta sõitis kolm korda ära välismaale.

Küll aga saab samas lauses iteratiivset tegevust väljendada siis, kui asendada perfektiivse aspekti verb imperfektiivsega (täpsemalt vt selle kohta Šatunovski 2009: 295-296):

(6c) Он три раза уезжал за границу.

Perfektiivse aspekti verbid tähistavad iteratiivseid tegevusi järgmistes lausetes $(7 \mathrm{a}, 8 \mathrm{a})$, eesti keeles annavad iteratiivsuse tähenduse edasi leksikaalsed vahendid: kolm korda, sada korda (7b, 8b):

(7а) Осипов обнял его и трижды поцеловал в губы. (В. Гроссман)

(7b) Ossipov aga embas teda ja andis talle kolm korda suud. (Tlk. A. Blumenfeld)

(8а) Я себя сто раз прокляла - ты не знаешь. (В. Распутин)

(8b) Sada korda needsin ennast ära - sa ei tea. (Tlk. V. Krimm) 


\subsection{Temporaaladverbiaalid}

Temporaaladverbiaalid jagunevad nelja rühma, vastavalt sellele, kas need näitavad: a) toimumisaega, b) ajapiiri, c) kestust või d) korduvust. Kaht esimest võib nimetada ajastavateks, kaht viimast kvantifitseerivateks adverbiaalideks (EKG II 1993: 77).

Iteratiivsust väljendavad näiteks korduvust märkivad (sageli, iga päev, igal aastal vms) või suhet loovad adverbiaalid (päevas, päeva kohta, tunnis vms). Korduvust näitavate temporaaladverbiaalide üksikasjalikumat liigitust vt (EKG II 1993: 84-86).

Temporaaladverbiaalid aitavad iteratiivset situatsiooni kirjeldada nii vene kui ka eesti keeles.

(9a) Каждый день в четыре часа утра в темноте под крики и брань полицейских, под плётками, хлыстами, ударами прикладов, под собачий лай рабочие колонны выстраивались на улице... (А. Рыбаков)

(9b) Iga päev kell neli hommikul pimedas, politseinike kisa ja sõimu saatel, piitsa- ja nuudhoopide, püssipäralöökide ja koerte haukumise saatel rivistusid tööliste kolonnid tänavale... (Tlk. L. ja P. Mõtsküla)

(10а) С тех пор мычасто виделись и неизменно ругались. (С. Довлатов)

(10b) Hiljem saime tihti kokku ja läksime alati riidu. (Tlk. V. Matsov)

Erinevus on aga selles, et vene keeles võib sellel leksikaalsel vahendil olla vaid toetav funktsioon, samal ajal kui eesti keeles ilma täpsustavat adverbiaali kasutamata ei pruugigi tegevuse iteratiivsus üldse selguda.

Kuna näitelauses (11b) ei ole verbi olema korratud (erinevalt originaaltekstist), siis viitabki olukorra iteratiivsusele vaid väljend isegi korduvalt.

(11a) - вам не приходилось, гражданин, бывать когда-нибудь в лечебнице для душевнобольных?

- Иван!.. - тихо воскликнул Михаил Александрович.

Но иностранец ничуть не обиделся и превесело рассмеялся.

- Бывал, бывал и не раз! - вскричал он, смеясь, но не сводя несмеющегося глаза с поэта... (М. Булгаков) 
(11b) "Kodanik, kas teil pole kunagi juhust olnud viibida vaimuhaiglas?" "Ivan!..." hüüatas Mihhail Aleksandrovitš vaikselt.

Kuid välismaalane ei olnud põrmugi solvunud, ta puhkes lustakalt naerma.

“On, ja isegi korduvalt!” hüüdis ta naerdes, kuid ei pööranud poeedilt tögavat pilku, milles polnud naeru varjugi. (Tlk. M. Varik ja J. Ojamaa)

\subsection{Reduplikatsioon}

Verbi (aga mitte ainult) reduplikatsioon on iteratiivse tegevuse edasiandmiseks kasutatav mõlemas vaadeldavas keeles, vt näitelaused (12a, 12b) ja (13a, 13b). Eesti keeles võib konjunktsioonita või konjunktsiooniga rinnastav reduplikatsioon väljendada nii iteratiivset kui ka duratiivset tegevust (Erelt \& Punttila 1999: 8). Nt: nad kõndisid ja kõndisid, aga maja ei paistnud ikka veel - verbi kordamine viitab pikaajalisele duratiivsele tegevusele. Samal ajal lauses Ta luges ja luges, aga ei saanud kirjast aru väljendab verbi reduplikatsioon iteratiivset tegevust, ehk ta luges mitu korda, aga ei saanud kirjast aru.

(12а) Карташев блаженно улыбался, поворачивался и, энергично срывая с головы шапку, все кланялся и кланялся. (Н. ГаринМихайловский)

(12b) Kartašov naeratas õndsalt, vahtis järjest tagasi, tõmbas aeg-ajalt mütsi peast ning muudkui kummardas ja kummardas. (Tlk. J. Piik)

(13a) Часто не подходила к телефону, когда он звонил. Правда, он два или три раза бывал у нас дома, случалось, ходила с ним в театр. Только очень редко. А он звонил и звонил... (А. Чаковский)

(13b) Kui ta helistas, ei läinud ma tihti telefoni juurdegi. Tõsi küll, paar korda tuli ta meie poole, vahel käisin ma temaga teatris. Kuid väga harva. Tema aga muudkui helistas ja helistas... (Tlk. J. Jürna)

Näitelausetes (12b) ja (13b) on eesti tõlkijad pidanud vajalikuks rõhutada tegevuse iteratiivsust lisaks verbide kummardas/helistas reduplikatsioonile täiendavalt veel ka adverbi aeg-ajalt ja kestusadverbiaaliga muudkui. 
Vene keeles võib korduda mitte ainult verbivorm, vaid ka konjunktsioon, vt näitelause (14a).

(14a) Те наклонились к нему с обеих сторон, и он сказал, но уже без всякого акцента, который у него, чёрт знает почему, то пропадал, то появлялся. (М. Булгаков)

(14b) Mõlemad kummardusid professori poole ja too alustas, rääkides taas vähimagi aktsendita, mis tal kurat teab miks kord kadus ja siis jälle läbi lõi. (Tlk. M. Varik ja J. Ojamaa)

\subsection{Objekti kääne}

Nii nagu verbiaspekt on eelkõige vene keele vahend iteratiivse tegevuse väljendamiseks, nii on objekti kääne sama tähenduse edasiandmise võimalus eesti keeles. Erinevad autorid on juhtinud tähelepanu ühele sellega seonduvale terminoloogilisele probleemile, näiteks Vaiss viidates Nemvaltsile (2000: 19-20) leiab, et

Jaatava lause partitiivne objektivorm võib osutada nii tegevuse kui ka objekti piiritlematusele. Seepärast tundub aspekti puudutavas töös terminoloogiliselt vale nimetada imperfektiivsele olukorrale viitavat partitiivobjekti osasihitiseks või partsiaalobjektiks, kuna need terminid osutavad eelkõige objekti piiritlematusele. (Vaiss 2004: 34)

Seetõttu on Vaissi aspektile pühendatud magistritöös traditsiooniliste terminite partsiaal- ja totaalobjekt asemel neutraalsemad terminid partitiivne, nominatiivne ja genitiivne objekt. Neid oskussõnu kasutatakse ka käesolevas artiklis.

Vene keele imperfektiivsele aspektile (mis väljendab iteratiivset tegevust oluliselt sagedamini kui perfektiivne aspekt) vastab eesti keeles reeglina partitiivne objekt (15b), perfektiivsele aspektile (terminatiivne tegevus) aga genitiivne objekt (16b).

(15a) Одно из этих писем тетя Даша читала чаще других - так часто, что, в конце концов, я выучил его наизусть. (В. Каверин)

(15b) Ühte neist kirjadest luges tädi Daša sagedamini kui teisi - nii sagedasti, et see mulle lõpuks pähe jäi. (Tlk. M. Sillaots) 
(16а) Коровьев швырнул историю болезни в камин. (М. Булгаков)

(16b) Korovjev viskas haigusloo kaminasse. (Tlk. M. Varik ja J. Ojamaa)

\subsection{Verbi leksikaalne tähendus (frekventatiivverbid)}

Frekventatiiv- või iteratiivverbide all peetakse silmas tegusõnu, mille enda semantikas juba sisaldub korduvuse element. Vene keeles loetakse

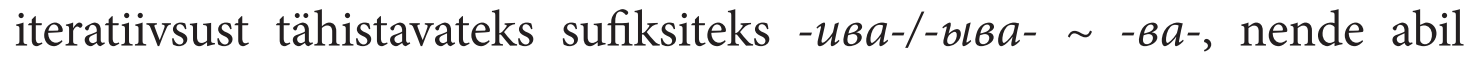
märgitakse tegevuse kordumist enamjaolt ühe ajahetke suhtes (Šeljakin 1983:194).

Reet Kasik on täheldanud, et eesti keeles puuduvad frekventatiivsust väljendavad juurverbid, mis tõttu saab seda tähendust verbile anda vaid sufiksi abil, peamised neist on 1) -le- (-skle-, -tle-) ja 2) - $i-,-u-$. Esimese grupi liited tähistavad juhuslikku ja korrapäratut iteratiivset tegevust, muuhulgas võivad muutuda ka toimimisviis, liikumissuund jms. Teise grupi sufiksite puhul korrapäratuse lisatähendust ei kaasne (Kasik 2004: 41). "Eesti keele käsiraamatus" eristatakse veel ka -ki-, -gi-, $-k u-j a-g u-$ frekventatiivliiteid, mis on samuti korrapärasuse-korrapäratuse suhtes neutraalsed (EKK 2007: 381).

Frekventatiivverbide abil iteratiivse tegevuse väljendamisvõimalus on huvipakkuv ka tõlke seisukohast (frekventatiivverbe eesti-vene tõlkes on vaadelnud nt Solovjova 2015).

(17a) Длинный меч его стучал по кожаному шнурованному сапогу. (М. Булгаков)

(17b) Tema pikk mõõk kõlksus vastu nööritud nahksaabast. (Tlk. M. Varik ja J. Ojamaa)

(18а) Варенуха, карауля дверь, подпрыгивал возле неё, подолгу застревая в воздухе и качаясь в нём. (М. Булгаков)

(18b) Ust valvav Verenuhha kargles läve ees, hüppas õhku ja jäi aeg-ajalt sinna hõljuma (Tlk. M. Varik ja J. Ojamaa)

Esineb juhtumeid, kus iteratiivse(te) tegevuse(te) väljendamist toetab lisaks frekventatiivverbile ka adverb (19a) ja (19b). Antud näitelausete puhul on see põhjendatav sellega, et ilma adverbideta иногда - mõnikord 
säiliks küll tegevuse постукивать - kõpsutama iteratiivsus, kuid näiteks akna taha seisma jäämist võiks vaadelda ka kui vaid korra asetleidnud sündmust.

(19a) Иногда она шалила и, задержавшись у второго оконца, постукивала носком в стекло. (М. Булгаков)

(19b) Mõnikord oli ta vallatu, jäi akna taha seisma ja kõpsutas kinganinaga vastu klaasi. (Tlk. M. Varik ja J. Ojamaa)

\subsection{Ajavormid}

Eespool oli juba juttu sellest, et iteratiivset tegevust võivad väljendada nii verbi preesensi-, preteeritumi- kui ka futuurumivormid. Eesti keeles sobivad väga hästi iteratiivse olukorra tähistamiseks ka liitajavormid: perfekt ja pluskvamperfekt. “Täis- ja enneminevik, mis võtavad mingi kindla vaatlushetke seisukohalt kokku enne seda toimunu, ei seostu tavaliselt kindlat ajakohta märkiva ajamäärusega, küll aga ajavahemikku, kestust, sagedust või korduvust märkiva ajamäärusega” (EKG II 1993: 80).

Perfekti puhul peetakse silmas eelkõige kogemusperfekti ja inklusiivset perfekti. Comrie (1995: 56-61) eristas nelja perfektitüüpi, eesti keeleteadusesse jõudsid need Metslangi ja Erelti tööde kaudu (Metslang 1997b; Erelt \& Metslang 1998; Metslang jt 2003). Perfekti kasutatakse iteratiivse olukorra edasiandmiseks näites (20b).

(20а) Господь меня наказует за скверну мою, - с чувством продолжал Никанор Иванович, то застегивая рубашку, то расстегивая, то крестясь, - брал! Брал, но брал нашими советскими! Прописывал за деньги, не спорю, бывало. (М. Булгаков)

(20b) “Issand tahab mind nuhelda mu patutegude eest," jätkas Nikanor Ivanovitš tundeküllaselt, ise särki kinni ja lahti nööpides ning risti ette lüües. "Jah, olen võtnud! Olen võtnud küll, aga meie, Nõukogude raha! Olen raha eest sisse kirjutanud, ei aja tagasi, on ette tulnud. (Tlk. M. Varik ja J. Ojamaa) 
Loomulikult võivad ka perfektivormi puhul aidata iteratiivset tegevust väljendada erinevad temporaaladverbiaalid, vt näitelause (21b).

(21a) Три раза приезжал я за Катериной. И три раза она отказывалась ехать со мной. (А. Кульбакин)

(21b) Kolm korda olen ma Katariinale järele sõitnud. Ja kolm korda on ta keeldunud minuga sõitmast.

Eesti keele pluskvamperfektiga saab tähistada enne teist tegevust toimuva tegevuse iteratiivsust või duratiivsust ning kirjeldada kaugel minevikus toimuvat tegevust tema duratiivsuses ja pidevas iteratiivsuses (Päll jt 1962: 160). Ka pluskvamperfekti puhul võivad iteratiivsuse tähistamisel abiks olla temporaaladverbiaalid. Vene keeles on vasteks imperfektiivse aspekti verbid.

(22a) Kõrtsis oli ta viimastel aastatel käinud üksnes harva ega jäänud sinna kauaks. (V. Tauli)

(22b) В трактир он в последние годы ходил редко и не засиживался там.

(23a) Viiel korral oli tahetud midagi ütelda ja on paiguti öeldudki. (J. Oks)

(23b) В пяти случаях хотели что-то сказать, и когда-то что-то было и (вы)сказано.

\subsection{Kontekst}

Nagu juba mainitud, väljendub eesti keeles aspektuaalsus sageli terves lauses. Tegelikkuses esineb olukordi, kus ka ühest lausest ei piisa, et mõista, kas tegevus on iteratiivne või mitte. Sellisel juhul on abi laiemast kontekstist. Originaalteksti (24a) puhul ei teki kahtlustki, et tegevus on iteratiivne, samal ajal, kui eestikeelne lause (24b) pakub rohkem kui ühte tõlgendusvõimalust.

(24a) За десять минут я садился к оконцу и начинал прислушиваться, не стукнет ли ветхая калитка. (М. Булгаков)

(24b) Kui oli jäänud kümme minutit, istusin ma akna alla ja kuulatasin, kas ei kolksata pehkinud jalgvärav. (Tlk. M. Varik ja J. Ojamaa) 
Selguse tegevuse iseloomu kohta saab alles siis, kui kaasata laiem kontekst (25).

(25) Ta käis minu pool iga päev, ja ma hakkasin teda ootama juba hommikul. See ootamine väljendus selles, et ma tõstsin laual asju sinnatänna. Kui oli jäänud kümme minutit... (Tlk. M. Varik ja J. Ojamaa)

\section{Duratiivse tegevuse väljendusvõimalused vene ja eesti keeles}

\subsection{Verbiaspekt}

Maslov on vene keele kohta öelnud, et duratiivse tegevuse väljendamist tuleb pidada imperfektiivse aspekti kõige spetsiifilisemaks tähenduseks, kuna vaid selles tähenduses ei saa imperfektiivse aspekti verbivormi asendada perfektiivse aspekti omaga (Maslov 2004: 100).

Näitelauses (26a) on üks ja sama verb esindatud nii perfektiivses (умер) kui ka imperfektiivses aspektis (умирал), millest esimene tähistab terminatiivset tegevust ja teine protsessi, mida toonitab veelgi ka duratiivsusele viitav viisiadverbiaal (мучительно). Eestikeelses lauses (26b) ei ole verbivormis mitte mingisugust erinevust ning olukorra duratiivsuse tähendus jääb tervikuna vaid viisiadverbiaali piinarikkalt kanda.

(26а) В тот же вечер умер капитан Никитенко, он мучительно умирал... (И. Эренбург)

(26b) Tol õhtul suri kapten Nikitenko; ta suri piinarikkalt... (Tlk. A. Kurfeldt)

Tegelikult on antud juhul ka eesti keeles soovi korral võimalik veidi rohkem toonitada erinevust kahe tegevuse vahel, kasutades näiteks perfektiivsusmarkerit: Tol óhtul suri kapten Nikitenko ära... "Eesti keele seletava sõnaraamatu" (EKSS 2009) järgi rõhutab surema tegevuse terminatiivsust ära.

Venekeelse imperfektiivse verbi умирать kasutusvõimaluste valik on lai. Lisaks sellele, et kõnealuse verbivormiga saab tähistada tegevust selle duratiivsuses, on võimalik väljendada ka minevikulist protsessi, 
mis tegelikult ei ole veel alanudki. Võrreldes näitelauseid (27a) ja (27b) näeme, et eesti keeles on toimunud huvitav transformatsioon, mis esmapilgul ei pruugi näida väga loogiline ega põhjendatud.

(27a) Он умирал двадцати семи лет, здоровый и сильный; прощаясь с товарищами, он помнил, что одному из них задал довольно посторонний вопрос и даже очень заинтересовался ответом. (Ф. Достоевский)

(27b) Ta pidi surema kahekümne seitsme aastasena, terve ja tugeva mehena; kaaslastega hüvasti jättes esitas ta ühele neist võrdlemisi kõrvalise tähtsusega küsimuse, nagu ta mäletas, ja oli vastusest vägagi huvitatud. (Tlk. M. Sillaots)

Kui aga vaadata laiemat konteksti, siis on mõistetav, miks tõlkija on leidnud just sellise lahenduse. Nimelt on tegu mehega, kes ootab oma surmaotsuse täideviimist, aga viimasel hetkel antakse talle armu. Ilmselt seetõttu ei pidanudki eesti tõlkija sobivaks kasutada näiteks supiini inessiivi ehk mas-tarindit: oli suremas, sest see tähendaks, et protsess (suremine) oleks juba alguse saanud, aga lähtudes kontekstist on selge, et nii see ei ole.

Ka verbi убивать 'tapma' kasutamine imperfektiivses aspektis duratiivse tegevuse väljendamiseks (28a) võib eesti keele loogika seisukohast tunduda kummaline, sest näib, et see tegevus peaks pigem olema terminatiivne ja mitteduratiivne.

(28а) - Меня убивали, да не убили, вот почему я здесь. (А. Толстой)

(28b) "Mind taheti tappa, kuid ei saadud, sellepärast olen siin." (Tlk. D. Vaarandi)

Näitelause (28b) puhul võib muidugi arutleda selle üle, et kas taheti tappa on kõige täpsem tõlkevariant. Arusaadavalt tahab tõlkija anda mõista, et tegevust ei viidud lõpule. Aga tahtmine tähendab pigem lihtsalt abstraktset soovi. Variandina tuleks ehk kõne alla: üritati tappa, mis tähendab samuti seda, et tegevust ei viidud lõpuni, kuid samas on selge, et see ei jäänud pelgalt soovi tasandile.

Harvad pole ka need juhud, kui lähtudes konkreetsest aspektivormist tuleb eestikeelses tekstis kasutada hoopis teise leksikaalse tähendusega 
verbe (29a, 30a) ja (29b, 30b). Verbipaari доставать - достаmь vasteteks on verbid võtma ja välja võtma, kuid antud juhtudel on tõlkijad eelistanud kasutada verbi, mille leksikaalses semantikas sisaldub duratiivsuse element. Otsima on duratiivne tegevus, sõltumata sellest, kui pikalt konkreetne otsing aega võtab.

(29a) Он стоял, не снимая пальто, и что-то доставал из кармана. (Л. Толстой)

(29b) Vronski seisis, palitu seljas ja otsis midagi taskust. (Tlk. S. Holberg)

(30a) Тот сидел на камне у самой воды и что-то доставал из полевой сумки. (О. Куваев)

(30b) Too istus üsna vee ääres kivil ja otsis midagi oma välipaunast. (Tlk. V. Krimm)

\subsection{Temporaal- ja viisiadverbiaalid}

Temporaal- ja viisiadverbiaalide kasutamine duratiivse tegevuse väljendamiseks vaadeldavates keeltes sarnaneb adverbiaalide kasutamisele iteratiivse tegevuse edasiandmiseks. Vene keeles on neil eelkõige toetav funktsioon (31a, 32a), samal ajal kui eesti keeles võivad need olla ainsaks vahendiks tegevuse duratiivsuse tähistamisel (31b, 32b).

(31a) Набрав после этого номер Лиходеевской квартиры, Варенуха долго слушал, как густо гудит в трубке. (М. Булгаков)

(31b) Sedamaid valis Varenuhha selle numbri ja kuulas tükk aega pikki madalaid signaale (Tlk. M. Varik и J. Oјamaa)

(32а) - Но меня, конечно, не столько интересуют автобусы, телефоны и прочая...

- Аппаратура! - подсказал клетчатый.

Совершенно верно, благодарю, - медленно говорил маг тяжелым басом, - сколько гораздо более важный вопрос: изменились ли эти горожане внутренне? (М. Булгаков)

(32b) "Kuid muidugi ei huvita mind mitte niivõrd autobussid, telefonid ja muu..."

"Aparatuur!" ütles ruuduline ette. 
“Täiesti õige, tänan," ütles maag aeglaselt raske bassihäälega, "kuivõrd hoopis tähtsam küsimus: kas linlased on sisemiselt muutunud?" (Tlk. M. Varik и J. Ojamaa)

Eestikeelses tekstis on ainsaks tegevuse duratiivsusele viitavaks vahendiks viisiadverbiaal aeglaselt, mis on veelgi olulisem seetõttu, et verb ütles vastab pigem venekeelsele verbile сказал, mis väljendab eelkõige momentaanset, mitteduratiivset tegevust.

\subsection{Reduplikatsioon}

Nagu öeldud, võib verbi reduplikatsioon väljendada iteratiivset, aga ka duratiivset tegevust.

(33а) И такая далекая, трудная дорога раскинулась между этими двумя словами, что я шел и шел по ней, отдыхал и снова шел, а все не видать было ни конца ни края! (В. Каверин)

(33b) Ja nii raske, pikk tee oli nende kahe sõna vahel, et ma käisin ja käisin seda teed mööda, puhkasin ja käisin uuesti, aga lõppu ei olnud ega olnud näha! (Tlk. M. Sillaots)

Kohati võib jääda mulje, et verbi reduplikatsioon ei ole eesti keeles ehk nii levinud viis tegevuse duratiivsuse edasiandmiseks kui vene keeles. Järgnevates näitelausetes on näha, et eesti tõlkijad on kasutanud muid vahendeid duratiivsuse säilitamiseks.

(34a) ...вдруг пришел воротившийся из города обломовский мужик, и уж он доставал, доставал из-за пазухи, наконец насилу достал скомканное письмо на имя Ильи Иваныча Обломова. (И. Гончаров)

(34b) ... astus sisse üks Oblomovka talupoeg, kes oli parajasti linnast koju jõudnud, koplas hea tükk aega põues ja võttis sealt viimaks suure vaevaga välja mäkerdatud kirja, mis oli adresseeritud Ilja Ivanovitš Oblomovile. (Tlk. A. H. Tammsaare)

(35a) Но Анатолий шел и шел по берегу, не разбирая дороги, стараясь как можно скорее уйти от этого места... (А. Чаковский) 
(35b) Anatoli aga läks teed valimata edasi, püüdes võimalikult kiiresti sellest kohast eemale jõuda... (Tlk. J. Jürna)

Näites (34b) ei ürita tõlkija tegevuse duratiivsust anda edasi verbi reduplikatsiooniga, nagu seda on tehtud originaaltekstis, vaid selle asemel kasutatakse dialektismi koplama ja lisaks veel väljendit hea tükk aega. Ka lauses (35b) on loobutud verbi dubleerimisest.

\subsection{Objekti kääne}

Nii nagu partitiivne objekt võib väljendada iteratiivsust, võib see anda edasi ka duratiivset tegevust, vt näide (36b) ja (37b).

(36а) - Вот тебе и муж предоставлен. Убивали, да не убили. (А. Толстой)

(36b) "Võta nüüd mees oma hoole alla. Nad tapsid teist, aga ei tapnud päriselt ära. (Tlk. А. Курфельд)

(37a) Шофер грузовой машины со злым лицом заводил мотор. (М. Булгаков)

(37b) Vihane veoauto juht väntas mootorit käima. (Tlk. M. Varik ja J. Ojamaa)

Võib leida ka vastupidiseid näiteid, kus originaalis ei ole duratiivset tegevust, aga tõlkes see ilmub. Näiteks Jevgeni Griškovetsi näidendi eestikeelne pealkiri:

(38а) Как я съел собаку? (Е. Гришковец)

(38b) Kuidas ma koera sõin? (Tlk. Jaan Ross)

Siinkohal tuleb pöörata tähelepanu kahele asjaolule:

1) venekeelne väljend (perfektiivse aspekti verbivormiga) съел собаку на чем-либо tähendab milleski suuri kogemusi ja põhjalikke teadmisi omandama. Võib olla on just fraseologismi semantika tinginud selle, et eestikeelses tõlkes väljendatakse protsessi (mida originaalis ei ole), kuna ka kogemuste ja teadmiste omandamine on duratiivne tegevus; 
2) ei saa täielikult välistada varianti, et tõlkija siiski viitab tegevuse terminatiivsusele ja objekt (koer) on tegelikult genitiivis. Eesti keeles on terve hulk substantiive, mille genitiiv ja partitiiv (mõningatel juhtudel ka nominatiiv) langevad kokku. Siiski võib eeldada, et juhul kui tõlkija oleks originaali eeskujul soovinud rõhutada tegevuse terminatiivsust, oleks ta tõenäoliselt lisanud perfektiivsusmarkeri ära.

\section{5. mas-tarind}

Eesti keeles eksisteerib spetsiaalne perifrastiline verbivorm duratiivse situatsiooni väljendamiseks: olema + supiini inessiiv, kui viimane märgib mitteterminatiivset tegevust (EKG II 1993: 32). Progressiivtarindit on põhjalikult uurinud Helle Metslang kolmeosalises artiklis "Kas eesti keeles on olemas progressiiv?" ning ta väidab, et “Tarind väljendab seisundit, mis kehtib vaatlushetkel. Selleks on olevikulise abiverbi korral (on toimumas) üldjuhul kõnehetk, lihtminevikulise abiverbi korral (oli toimumas) mingi kindel minevikuhetk" (1993: 334).

Progressiivtarindile saavad vene keeles olla vasteks nii imperfektiivse aspekti preesensi- (39b) kui ka preteeritumivormid (40a).

(39a) Mehed on aasal heina niitmas.

(39b) Мужчины косят сено на лугу.

(40а) Он умирал. Казалось, при его здоровье, силе он мог выдержать и не такие лишения. (Д. Гранин)

(40b) Pürg oli suremas. Paistis, et tema tervis ja jõud oleksid pidanud välja kannatama hullemaidki katsumusi. (Tlk. M. Lott)

\subsection{Verbi leksikaalne tähendus}

Duratiivset tegevust väljendavaid verbe nimetatakse kontinuatiivideks (EKK 2007: 175). Reet Kasiku käsitluses väljendavad nii frekventatiivsed kui ka kontinuatiivsed verbid pikema duratiivsusega tegevuslaadi ning iteratiivsus/duratiivsus sõltub alusverbist. Näiteks -le liitega verbid 
võivad tähistada iteratiivseid tegevusi: hõiklema, võnklema, hüplema, kekslema jne, aga ka duratiivseid tegevusi: tuisklema, ekslema jne. Vaid loodushääli jäljendavate deskriptiivverbide puhul on eesti keeles duratiivse ja iteratiivse tegevuse märkimiseks eraldi tuletusliited - iteratiivsuse tähistamiseks kasutatakse $u$ - ja $i$-tuletisi (niutsuma), duratiivsuse väljendamiseks ise-liitelisi verbe (krabisema). tse-tuletised märgivad vähehaavalist pidevat tegevust (ravitsema) (Kasik 2004: 51-53).

(41a) Кстати: этим делом следствие занималось особенно внимательно. (М. Булгаков)

(41b) Muide, selle asjaga tegelesid uurijad eriti hoolikalt. (Tlk. M. Varik ja J. Ojamaa)

(42a) Хохот звенел под колоннами и гремел, как в бане. (М. Булгаков)

(42b) Naer kaikus sammaste vahel ja mürises nagu saunas. (Tlk. M. Varik ja J. Ojamaa)

Duratiivset tegevust võivad väljendada ka ilma spetsiaalse morfoloogilise tunnuseta verbid (nt seisundi-, tundeverbid jms).

(43a) Человечество любит деньги, из чего бы те ни были сделаны, из кожи ли, из бумаги ли, из бронзы или из золота. (М. Булгаков)

(43b) Inimkond armastab raha, millest see ka tehtud ei oleks, olgu nahast, paberist, pronksist või kullast. (Tlk. M. Varik ja J. Ojamaa)

Vene keeles võib lisaks lihtsalt olukorra duratiivsusele väljendada veel ka “üleliia kaua kestvat” tegevust е чрезмерно-длительное действие (Šeljakin 2001: 92). Selleks moodustatakse perfektiivse aspekti verb järgmise mudeli järgi: prefiks $3 a-$ + verb + postfiks -cя, nt заuгpambcя - (kauaks) mängima jääma, засидеться - (pikaks ajaks) istuma jääma jne. Eestikeelsetes näitelausetes rõhutatakse duratiivsust leksikaalsete vahenditega (44b) või loobutakse üldse verbi kasutamisest (45b).

(44a) - Дорогая Анна Степановна, это страшное свинство, что я так засиделся с Ледковым, - сказал я, заехав к Анне Степановне ночью и найдя её поджидающей меня за накрытым столом. (В. Каверин) 
(44b) "Kallis Anna Stepanovna, see on hirmus sigadus, et ma nii kauaks Ledkovi juurde istuma jäin," ütlesin ma öösel Anna Stepanovna juurde jõudes ja leides, et ta mind kaetud laua juures ootab. (Tlk. M. Sillaots)

(45a) “Жулик. Без совести. Может по миру пустить меня и сам этого не заметит. И не из жадности разорит, а просто - заиграется”. (М. Горький)

(45b) "Suli. Ilma südametunnistuseta. Võib mu kerjuseks teha ega märkagi seda ise. Ja ei laosta ahnuse pärast, vaid lihtsalt liigsest mänguhoost” (Raamatus puudub tõlkija kohta informatsioon)

\section{Järeldused}

Iteratiivse või duratiivse tegevuse väljendamiseks on mitmeid erinevaid vahendeid nii eesti kui ka vene keeles. Mõningad väljendusvõimalused on ühised, aga mitmed on omased vaid ühele või teisele vaadeldavale keelele. Analüüsi tulemused on koondatud kahte järgnevasse tabelisse. Tabelis 1 on võrdlevalt esitatud iteratiivse ja Tabelis 2 duratiivse tegevuse väljendusvõimalused käsitletavates keeltes.

Tabelist 1 nähtub, et iteratiivse tegevuse väljendamiseks kasutatavad vahendid langevad vaadeldavatest keeltes enamjaolt kokku (seitsmest võimalusest kaks). Ainsateks eranditeks on aspektivorm vene ja objekti kääne eesti keeles. Ühtlasi võib väita, et teatud erinevused esinevad ka ühiste väljendusvõimaluste puhul, nii näiteks on temporaaladverbiaalide roll eesti keeles iteratiivse tegevuse edasiandmisel märkimisväärselt suurem kui vene keeles, kus neil on enamjaolt vaid toetav eesmärk.

Duratiivse tegevuse puhul võib tabelist 2 näha, et artiklis vaadeldud väljendusvõimalustest pooled kattuvad (kuuest vahendist kolm). Sarnaselt iteratiivse tegevuse väljendamisele seisneb ka duratiivsuse puhul keeltevaheline erinevus vene aspektivormis ja eesti keele objekti käändes ning lisaks veel mas-tarindis. 
TABEL 1. Iteratiivse tegevuse väljendusvõimalused vene ja eesti keeles

\begin{tabular}{|l|l|l|}
\hline Väljendusvõimalus & \multicolumn{1}{|c|}{ Vene keel } & \multicolumn{1}{c|}{ Eesti keel } \\
\hline Verbiaspekt & $\begin{array}{l}\text { + (peamiselt imperfektiivne } \\
\text { aspekt, üksikutel juhtudel } \\
\text { perfektiivne aspekt) }\end{array}$ & - \\
\hline $\begin{array}{l}\text { Temporaal- } \\
\text { adverbiaalid }\end{array}$ & + (vaid toetav funktsioon) & $\begin{array}{l}\text { + (võib olla iteratiiv- } \\
\text { suse ainus väljendaja } \\
\text { lauses) }\end{array}$ \\
\hline Reduplikatsioon & + & + \\
\hline Objekti kääne & - & + (partitiivne objekt) \\
\hline $\begin{array}{l}\text { Verbi leksi- } \\
\text { kaalne tähendus } \\
\text { (frekventatiiv- } \\
\text { verbid) }\end{array}$ & + & + \\
\hline & $\begin{array}{l}+ \text { (iteratiivset tegevust on } \\
\text { võimalik väljendada nii } \\
\text { preteeritumi-, preesensi- kui } \\
\text { futuurumivormidega, kuid } \\
\text { ei saa väita, et mõni ajavorm } \\
\text { sobiks selle tähenduse } \\
\text { edasiandmiseks paremini, } \\
\text { kui teised) }\end{array}$ & $\begin{array}{l}+ \text { (eriti perfekt ja } \\
\text { pluskamperfekt) }\end{array}$ \\
Ajavormid & + & + \\
\hline Kontekst & t \\
\hline
\end{tabular}

TABEL 2. Duratiivse tegevuse väljendusvõimalused vene ja eesti keeles

\begin{tabular}{|l|l|l|}
\hline Väljendusvõimalus & \multicolumn{1}{|c|}{ Vene keel } & \multicolumn{1}{c|}{ Eesti keel } \\
\hline Verbiaspekt & $\begin{array}{l}\text { + (ainult imperfektiivne } \\
\text { aspekt) }\end{array}$ & - \\
\hline $\begin{array}{l}\text { Temporaal- ja vii- } \\
\text { siadverbiaalid }\end{array}$ & + (vaid toetav funktsioon) & $\begin{array}{l}\text { + (võib olla duratiiv- } \\
\text { suse ainus väljendaja } \\
\text { lauses })\end{array}$ \\
\hline Reduplikatsioon & + & + \\
\hline Objekti kääne & - & + (partitiivne objekti) \\
\hline Mas-tarind & - & + \\
\hline $\begin{array}{l}\text { Verbi leksikaalne } \\
\text { tähendus (konti- } \\
\text { nuatiivverbid) }\end{array}$ & + & + \\
\hline
\end{tabular}


Analüüs lubab vastata artikli sissejuhatuses püstitatud kahele uurimisküsimusele. Esiteks, selles osas, mis puudutab eesti keele võimalusi vene keele verbiaspekti kompenseerimiseks, tõi tõlkenäidete analüüs selgelt esile asjaolu, et eesti keeles tuginetakse iteratiivsuse või duratiivsuse väljendamisel suures osas temporaal- ja viisiadverbiaalidele. Harvad pole juhud, kui ilma konkreetse adverbita ei olegi võimalik kirjeldatud tegevuse toimumise iseloomu kindlaks teha. Vene keeles on iteratiivse või duratiivse tegevuse tähenduse kandjaks eelkõige verbiaspekt ning teistel leksikaalsete vahenditel on enamjaolt vaid toetav funktsioon.

Teiseks, tuleb tõdeda, et kattuvaid duratiivse ja iteratiivse tegevuse väljendusvõimalusi on vaadeldavates keeltes oluliselt rohkem kui erinevusi. Esimeste hulka kuuluvad nt temporaaladverbiaalid, reduplikatsioon, ajavormid ja kontekst. Keeleliste vahendite hulka, mis eksisteerivad vaid ühes uurimusse kaasatud keeles, võib lugeda verbiaspekti, objekti käänet ja mas-tarindit.

Analüüsi tulemused on rakendatavad tulevastes kontrastiivsetes ja tüpoloogilistes uurimustes. Samuti on neid võimalik kasutada vaadeldavate keelte õpetamisel, abiks on analüüsi põhjal koostatud tabelid, mis annavad selge ülevaate keeltevahelistest sarnasustest ja erinevustest iteratiivsuse ning duratiivsuse väljendamisel. Viimaks võiks artiklis esitatud tulemustest kasu olla tõlketeooria, eelkõige aga praktilise tõlke õpetamisel. Enamjaolt eeldatakse, et tõlkija teeb keelt ja grammatikat puudutavad otsused alateadlikul, siiski näitavad just taolised uurimused, et mõnikord on oluline veidi teadlikumalt kaaluda, milline sihtkeele grammatiline vahend sobib kõige paremini lähteteksti tähenduse edasiandmiseks, et ei kannataks tõlke täpsus, väljendusrikkus ega loomulikkus.

\section{Materjali allikad}

Булгаков, Михаил 1980. Мастер и Маргарита. Рассказы. Москва: Художественная литература.

Bulgakov, Mihhail 1995. Meister ja Margarita. Tlk. Maiga Varik, Jüri Ojamaa. Tallinn: Varrak.

Достоевский, Федор 1973. Идиот. Ленинград: Наука. 
Dostojevski, Fjodor 1975. Idioot. Tlk. Marta Sillaots. Tallinn: Eesti Raamat. Довлатов, Сергей 1991. Ремесло; Наши. Таллинн.

Dovlatov, Sergei 1995. Kompromiss; Meie omad. Tlk. Vilma Matsov. Tallinn: Kupar.

Эренбург, Илья 1948. Буря. Москва: Советский писатель.

Ehrenburg, Ilja 1949. Torm. 1. raamat. Tlk. Aita Kurfeldt. Tallinn: Ilukirjandus ja Kunst.

Garin-Mihhailovski, Nikolai 1961. Gümnasistid. Tlk. Jüri Piik. Tallinn: Eesti Riiklik Kirjastus.

Гарин-Михайловский, Николай 1988. Детские годы Багрова-внука: Гимназисты. Ленинград: Художественная литература.

Гончаров, Иван 1979. Обломов. Москва: Правда.

Gontšarov, Ivan 1979. Oblomov. Tlk. A. H. Tammsaare. Tallinn: Eesti Raamat.

Горький, Максим 1948. Дело Артамоновых. Москва: Ленинград: Гослитиздат. Gorki, Maksim 1950. Artamonovite ettevõte. Tallinn: Eesti Riiklik Kirjastus.

Гранин, Даниил 1988. Зубр. Москва: Художественная литература.

Granin, Daniil 1990. Pürg. Tlk. Mare Lott. Tallinn: Eesti Raamat.

Гришковец, Евгений 2001. Город: Сб. пьес. Москва.

Griškovets, Jevgeni 2006. Kuidas ma koera sõin; Vene rännumehe ülestähendused. Tlk. Jaan Ross. Tallinn: Kultuurileht.

Гроссман, Василий 1990. Жизнь и судьба. Таллинн: Ээсти Раамат.

Grossman, Vassili 2003. Elu ja saatus. Tlk. Asta Blumenfeld. Tallinn: Eesti Raamat. Каверин, Вениамин 1956. Два капитана. Ставрополь: Книжное издательство. Kaverin, Veniamin 1959. Kaks kaptenit. Tlk. Marta Sillaots. Tallinn: Eesti Riiklik Kirjastus.

Кульбакин, Анатолий 1983. Глагольные временные формы в немецком языке и их видо-временные эквиваленты в русском языке. Воронеж: ВГПИ. Kuvajev, Oleg 1977. Territoorium. Tlk. Virve Krimm. Tallinn: Eesti Raamat. Куваев, Олег 1984. Территория. Москва: Пофиздат.

Лукьяненко, Сергей 2003. Ночной Дозор. Москва: АСТ.

Lukjanenko, Sergei 2008. Öine vahtkond. Tlk. Tanel Rõigas. Tallinn: Varrak.

Маринина, Александра 1995. За все надо платить. Москва: Эксмо.

Marinina, Aleksandra 2002. Kõige eest tuleb maksta. Tlk. Peedu Haaslava. Tallinn: Avita.

Oks, Jaan 1967. Vaevademaa. Tallinn: Perioodika.

Распутин, Валентин 1976. Повести: Прощание с Матерой; Живи и помни; Последний срок; Деньги для Марии. Москва: Молодая гвардия.

Rasputin, Valentin 1977. Ela ja mäleta. Tlk. Virve Krimm. Tallinn: Eesti Raamat. 
Рыбаков, Анатолий 1982. Тяжелый песок. Москва: Советский писатель.

Rõbakov, Anatoli 1983. Raske liiv. Tlk. Paul ja Linda Mõtsküla. Tallinn: Eesti Raamat.

Tauli, Valter 1980. Eesti grammatika II. Lauseõpetus. Finsk-ugriska institutionen. Uppsala.

Толстой, Алексей 1947. Полное собрание сочинений. Том 7, Хождение по мукам: трилогия: Сестры; Восемнадцатый год. Москва: Гослитиздат.

Tolstoi, Aleksei 1975. Kannatuste rada. 1.: Õed. Tlk. Justa Kurfeldt. Tallinn: Eesti Raamat.

Толстой, Алексей 1957. Повести и рассказы. Москва: Московский рабочий.

Tolstoi, Aleksei 1958. Siug. Tlk. Debora Vaarandi. Tallinn: Ajalehtede ja Ajakirjade Kirjastus.

Толстой, Лев 1976. Анна Каренина. Москва: Художественная литература.

Tolstoi, Lev 1978. Anna Karenina. 1. Tlk. Selma Holberg. Tallinn: Eesti Raamat.

Чаковский, Александр 1969. Блокада. Москва: Художественная литература.

Tšakovski, Aleksandr 1974. Blokaad. 1. Tlk. Juhan Jürna. Tallinn: Eesti Raamat.

\section{Kirjandus}

Argus, Reili 2007. Eesti keele verbi ajamorfoloogia ja aspektilisuse omandamisest ['Acquisition of Estonian verb morphology, tense and actionality']. - Emakeele Seltsi aastaraamat 52, 7-32.

Bondarko \& Bulanin 1967 = Бондарко, Александр, Лев Буланин. Русский глагол ['The Russian Verb']. Ленинград: Просвещение.

Bondarko 1971 = Александр Бондарко. Вид и время русского глагола ['Aspect and Tense of the Russian Verb']. Москва: Просвещение.

Comrie, Bernard 1995. Aspect. An Introduction to the Study of Verbal Aspect and Related Problems. Cambridge: Cambridge University Press.

Dahl, Östen 1985. Tense and Aspect Systems. Oxford: Blackwell.

EKG II = Erelt, Mati, Reet Kasik, Helle Metslang, Henno Rajandi, Kristiina Ross, Henn Saari, Kaja Tael, Silvi Vare 1993. Eesti keele grammatika II. Süntaks ['The Grammar of the Estonian Language II: Syntax']. Eesti Teaduste Akadeemia Keele ja Kirjanduse Instituut. Tallinn.

EKG I = Erelt, Mati, Reet Kasik, Helle Metslang, Henno Rajandi, Kristiina Ross, Henn Saari, Kaja Tael, Silvi Vare 1995. Eesti keele grammatika I. Morfoloogia. Sõnamoodustus ['The Grammar of the Estonian Language I: Morphology. Word-formation']. Eesti Teaduste Akadeemia Eesti Keele Instituut. Tallinn. 
EKK 2007 = Mati Erelt, Tiiu Erelt, Kristiina Ross. Eesti keele käsiraamat ['The Handbook of Estonian']. Tallinn: Eesti Keele Sihtasutus.

EKSS 2009 = Langemets, Margit, Mai Tiits, Tiia Valdre, Leidi Veskis, Ülle Viks, Piret Voll. Eesti keele seletav sõnaraamat ['The Explanatory Dictionary of Estonian']. Tallinn: Eesti Keele Sihtasutus.

Erelt, Mati, Helle Metslang 1998. Oma või võõras? [Our own or foreign?] - Keel ja Kirjandus 10, 657-668.

Erelt, Mati, Matti Punttila 1999. Suomalais-ugrilaisten kielten reduplikaatiosta ['Reduplication in Finno-Ugric languages']. - Lähivertailuja 10, 3-12.

Erelt, Mati 2013. Eesti keele lauseõpetus. Sissejuhatus. Öeldis ['Estonian Syntax. Introduction. Predicate']. Tartu: Tartu Ülikooli eesti keele osakond.

Eslon jt 1993 = Эслон, Пилле, Антс Пихлак. Вид и время (Сопоставительный очерк) ['Aspect and Tense (Comparative essay)']. Таллинн: Таллиннский педагогический университет.

Kangasmaa-Minn, Eeva 1985. Suomen verbi-ilmausten kvantiteetista ja kvaliteetista ['Quantitative and qualitative aspects of the Finnish verb expressions']. - Virittäjä 89, 429-446.

Kasik, Reet 2004. Eesti keele sõnatuletus ['Derivation in Estonian']. Tartu: Tartu Ülikooli Kirjastus.

Kupp-Sazonov 2012 = Сирье Купп-Сазонов. Значение конкуренции (синонимии) видов с точки зрения русско-эстонского перевода ['The meaning of competition (synonymy) of aspects from the point of view of Russian - Estonian translation']. - Русская филология 23. Сборник научных работ молодых филологов. Тарту: Издательство Тартуского университета, 164-169.

Kupp-Sazonov 2015 = Сирье Купп-Сазонов. О роли грамматики в переводе (на материале временных форм глагола в русском и эстонском языках) ['On the Role of Grammar in Translation (using Russian and Estonian tenses as an example)']. Dissertationes philologiae slavicae Universitatis Tartuensis. Tartu: University of Tartu Press.

Külmoja jt 2003 = Ирина Кюльмоя, Эда Вайгла, Майе Солль. Краткий справочник по контрастивной грамматике эстонского и русского языков ['Quick Reference Guide to Contrastive Grammar of Estonian and Russian']. Тарту: Tartu Ülikooli Kirjastus.

Maslov 1948 = Юрий Маслов. Вид и лексическое значение глагола в современном русском литературном языке ['Aspect and the lexical meaning of the verb in contemporary Standard Russian']. - Сер. лит. и яз. T. 7. 4, 303-316. Москва: АН СССР. 
Maslov 2004 = Юрий Маслов. Избранные труды. Аспектология. Общее языкознание ['Selected Writings. Aspectology. General Linguistic']. Москва: Языки славянской культуры.

Metslang, Helle 1993. Kas eesti keeles on olemas progressiiv? [Is there a progressive in Estonian?] - Keel ja Kirjandus 7, 326-334; 8, 410-417; 9, 470-476.

Metslang, Helle 1994. Temporal Relations in the Predicate and the Grammatical System of Estonian and Finnish. Oulu: Oulun Ylipisto.

Metslang, Helle 1997a. Eesti keele ja teiste soome-ugri keelte futuurumi arenguid [Developments of the future tense in Estonian and in other Finno-Ugric languages']. - Keel ja Kirjandus 4, 226-231.

Metslang, Helle 1997b. On the use of the Estonian past tense forms through the last one hundred years. - Mati Erelt (Ed.), Estonian: Typological studies 2. Tartu Ülikooli eesti keele õppetooli toimetised 8. Tartu, 98-145.

Metslang, Helle 2001. On the developments of the Estonian aspect. The verbal particle ära. - Östen Dahl, Maria Koptjevskaja-Tamm (Eds.), Circum-Baltic Languages. Vol. 2: Grammar and Typology. Amsterdam-Philadelphia: Benjamins, 443-479.

Metslang, Helle, Ingrid Krall, Renate Pajusalu, Kristi Saarso, Elle Sõrmus, Silvi Vare 2003. Keelehärm. Eesti keele probleemseid piirkondi ['Language Frustration. Some Problematic Areas of Estonian']. Tallinn: TPÜ Kirjastus.

Nemvalts, Peep 2000. Aluse sisu ja vorm: alusfraasi käändevaheldus tänapäeva eesti kirjakeeles ['The Content and the Form of the Subject. The Case Alternation of the Subject Phrase in Modern Standard Estonian']. Tallinn: Eesti Keele Sihtasutus.

Norvik, Miina, Piret Piiroja 2013. Aeg ja aspekt ['Tense and aspect']. - Eesti ja soome-ugri keeleteaduse ajakiri / Journal of Estonian and Finno-Ugric Linguistics, 53-72.

Padutševa 2009 = Елена Падучева. Лексическая аспектуальность и классификация предикатов по Маслову - Вендлеру ['Lexical Aspectuality and Classifications of Predicates According to Maslov and Vendler']. Вопросы языкознания 6. Москва: Наука, 3-20.

Petruhhina 2009 = Елена Петрухина. Русский глагол: категории вида и времени (в контексте современных лингвистических исследований) ['Russian Verb Category of Aspect and Tense (in the Context of Modern Linguistic Studies']. Москва: МАКС Пресс.

Pihlak 1978 = Антс Пихлак. Аспектуальность в эстонском языке (в сопоставлении с русским языком) [Aspect in Estonian (in comparison with the 
Russian']. - Семантика и функционирование категории вида русского языка. Вопросы русской аспектологии III. Тарту, 24-42.

Pihlak 1982 = Антс Пихлак. Отношение видов русского языка к эстонским временам. Вопросы сопоставительного изучения лексики и грамматики (на материале эстонского и русского языков) ['On the relation between the Russian category of aspect and the Estonian category of tense']. Таллин: Академия наук Эстонской ССР, 86-100.

Potebnja 1941 = Александр Потебня. Из записок по русской грамматике ['From Notes on Russian Grammar']. Ленинград: АН СССР.

Päll jt 1962 = Эдуард Пялль, Элиза Тотцель, Гвидон Тукумцев. Сопоставительная грамматика эстонского и русского языка ['Comparative Grammar of Estonian and Russian']. Таллин: Эстонское государственное издательство.

Rassudova 1982 = Ольга Рассудова. Употребление видов глагола в современном русском языке ['Aspectual Usage in Modern Russian’]. Москва: Русский язык.

Šatunovski 2009 = Илья Шатуновский. Проблемы русского вида ['Problems of Russian Aspect']. Москва: Языки славянских культур.

Seilenthal, Tõnu 1988. Aspektist ja muust eesti ja soome keeles ['About aspect and other in Estonian and Finnish']. - Lähivertailuja 3, 52-59.

Solovjova, Kristina 2015. Frekventatiivverbid Jaan Krossi romaanis "Kolme katku vahel" ja nende tõlkevasted vene keeles ['Frequentative verbs in Jaan Kross's novel "Between Three Plagues" and their Russian translations']. Bakalaureusetöö. Tartu Ülikool. http://hdl.handle.net/10062/47755

Sulkala, Helena 1996. Expression of aspectual meanings in Finnish and Estonian. - Estonian: Typological studies 1. Tartu Ülikooli eesti keele õppetooli toimetised 4. Tartu, 165-225.

Šeljakin 1983 = Михаил Шелякин. Категория вида и способы действия русского глагола ['Category of Aspect and Category of Aktionsart of Russian Verb’]. Таллинн: Валгус.

Šeljakin 2001 = Михаил Шелякин. Функциональная грамматика русского языка ['Functional Grammar of Russian']. Москва: Русский язык.

Zaliznjak \& Šmeljov 2000 = Анна Зализняк, Алексей Шмелев. Введение в русскую аспектологию ['Introduction to the Study of Russian Aspect']. Москва: Языки русской культуры.

Tamm, Anne 2004. Relations between Estonian verb, aspect, and object case. Phd dissertation. Budapest. 
Tommola 1986 = Ханну Томмола. Аспектуальность в финском и русском языках ['Aspectuality in Finnish and Russian']. Neuvostoliittoinstituutin Vuosikirja 28. Helsinki.

Vaiss, Natalia 2004. Eesti keele aspekti väljendusvõimalusi vene keele taustal ['The Expression of Aspect in Estonian in Comparison with Russian']. Magistritöö. Tallinna Ülikool. http://hdl.handle.net/10062/44143

Vendler, Zeno 1967. Linguistics in Philosophy. Ithaca, New York: Cornell University Press. 


\title{
On expressing iterative or durative action in Russian and Estonian
}

\author{
SIRJE KUPP-SAZONOV \\ University of Tartu
}

The article focuses on different ways for expressing iterative or durative action in Russian and Estonian. Comparing original Russian texts to their translation in Estonian, it is noticeable that in Estonian one has to use more linguistic features to express iterative or durative action than in Russian. In order to express those meanings in Russian it is very often enough to use a verb in the imperfect tense, while all other possible instruments (such as adverbs, reduplication of verbs, whole context, etc.) just have a supporting function. Meanwhile in Estonian, for example, adverbs can play the most significant role in expressing iterative or durative action and without them the sentence can be understood in more than one way. In the article numerous examples of iterative or durative action are presented and analysed. It is shown that both languages have some similar ways of expressing those meanings: for example, adverbials, context, reduplication of verbs, tenses, semantics of the verb etc. But there are also some tools that remain specific to one language; for Russian this is mainly verb tense, and for Estonian one can point to the object case and a construction of the verb to be (olema) + inessive form of the supine. The results of this analysis could be used in teaching Russian and Estonian, but also in the theory and practice of translation.

Keywords: contrastive analysis, iterativity, durativity, Russian, Estonian

\author{
Sirje Kupp-Sazonov \\ Tartu Ülikooli maailma keelte ja kultuuride kolledž \\ Lossi 3 \\ 51003 Tartu, Estonia \\ sirje.kupp-sazonov@ut.ee
}

